\title{
Klinikte Yararlı Anksiyete Sonlanım Ölçeği'nin Türkçe Versiyonunun Geçerliliği ve Güvenilirliği
}

\author{
Validity and Reliability of the Turkish Version of the Clinically Useful Anxiety Outcome Scale
}

Tokat Gaziosmanpașa Üniversitesi Tıp Fakültesi, Ruh Sağlığı ve Hastalıkları Anabilim Dal,

Tokat, Türkiye

Correspondence:

Zekiye ÇELİKBAŞ - Tokat Gaziosmanpaşa Üniversitesi Tip Fakültesi Ruh Sağlığı ve Hastalıkları Anabilim Dalı, Tokat, Türkiye

e-mail: zekiye.celikbas@gop.edu.tr

\section{Zekiye Çelikbaş, Sedat Batmaz, Esma Akpınar Aslan}

\section{Özet}

Rutin klinik uygulamadaki psikiyatrik bozuklukları tedavi ederken yanıtı ölçmek için standardize edilmiş ölçekler giderek daha fazla önerilmektedir. Klinikte Yararlı Anksiyete Sonlanım Ölçeği (KYASÖ), anksiyetenin șiddetini hızlı ve optimum düzeyde değerlendirmek için kullanılan kısa bir özbildirim ölçeğidir. Bu çalışmada KYASÖ’nün Türk toplumundaki geçerlilik ve güvenilirliği araştırılmıştır. Çalışmaya anksiyete bozukluğu, obsesif kompulsif bozukluk, travma sonrası stres bozukluğu tanılı olan 155 , geçmişte ve halen herhangi bir psikiyatrik tanısı olmayan 132 kişi alındı. Değerlendirme araçları olarak KYASÖ Türkçe formu, Durumluk - Sürekli Kaygı Ölçeği, Klinikte Yararlı Depresyon Sonlanım Ölçeği, Klinik Global İzlenim Ölçeği - Şiddet Alt Ölçeği kullanıldı. FACTOR 10.8.04 yazılımı ile açıklayıcı faktör analizi, çıkarılan faktörlerin ve ölçeğin tamamının iç tutarlılığı için Cronbach $a$ değerleri, düzeltilmiş madde - toplam korelasyonları ve madde silinirse Cronbach a değerleri, açılanan varyans, özdeğerler, maddelerin faktörlere yüklenme katsayıları ve ortak etken varyansları hesaplandı. Diğer analizler için MedCalc 17.2 yazılımı kullanıldı. Cronbach a değerleri KYASÖ için 0.957, KYASÖ-Bedensel (Somatik) Anksiyete alt ölçeği için 0.936 ve KYASÖ-Ruhsal (Psişik) Anksiyete alt ölçeği için 0.934 bulunmuştur. Madde çıkarılması ile ölçeğin tümünde iç tutarlılıkta önemli bir değişiklik gözlenmemiştir. Düzeltilmiş madde - toplam korelasyonları değerleri 0.466 - 0.792 arasında değişmiştir. Ölçeğin birlikte ve ayırt edici geçerliliği gösterilmiştir. KYASÖ’nün Türkçe formu, Türk toplumunda anksiyete şiddetini ölçen, klinik kullanım için uygun geçerli ve güvenilir bir ölçektir.

Anahtar Kelimeler: Anksiyete; ölçek; geçerlilik; güvenilirlik.

\section{Abstract}

Standardized scales are increasingly recommended to measure response when treating psychiatric disorders in routine clinical practice. The Clinically Useful Anxiety Outcome Scale (CUXOS) is a short self-report scale to evaluate the severity of anxiety quickly and optimally. In this study, validity and reliability of the CUXOS was investigated in a Turkish population. 155 patients with anxiety disorders, obsessive-compulsive disorder, posttraumatic stress disorder, and 132 participants with no history of psychiatric diagnosis were included in the study. As the assessment tools, the Turkish version of CUXOS, the State- Trait Anxiety Inventory, the Clinically Useful Depression Outcome Scale, the Clinical Global Impression Scale - Severity subscale were used. With FACTOR 10.8.04 software, explained variance, eigenvalues, loading factors and common factor variances were calculated. For the internal consistency, Cronbach $\alpha$ values, corrected itemtotal correlations and Cronbach $\alpha$ values of the extracted factors and the whole scale were calculated. MedCalc 17.2 software was used for these analyses. Cronbach $\alpha$ values were found to be 0.957 for CUXOS, 0.936 for CUXOS-Somatic subscale and 0.934 for CUXOS-Psychic subscale. No significant change in internal consistency was observed in the entire scale with the removal of the item. Adjusted item - total correlations values ranged from 0.466 to 0.792 . Convergent and discriminant validity of the scale were demonstrated. Turkish version of CUXOS is a valid and reliable scale that measures the severity of anxiety and suitable for clinical use in Turkish population.

Keywords: Anxiety; scale; validity; reliability. 


\section{Giriş}

Panik bozukluğu, yaygın anksiyete bozukluğu, sosyal anksiyete bozukluğu, özgül fobiler ve ayrilma anksiyetesi bozukluğu gibi rahatsızlıkları kapsayan anksiyete bozuklukları en yaygin ruhsal bozukluklardandır ve sağlık hizmetlerinde hastalığa bağlı yükü artışı ile ilişkilidir. Büyük popülasyon temelli çalışmalara göre, nüfusun \%33.7'si yaşamı boyunca en az bir anksiyete bozukluğundan etkilenmektedir (1).

Rutin klinik uygulamadaki psikiyatrik bozuklukları tedavi ederken yanıtı ölçmek için standardize edilmiş ölçekler giderek daha fazla önerilmektedir. Klinikte Yararlı Anksiyete Sonlanım Ölçeği (KYASÖ), anksiyetenin şiddetini hızlı ve optimum düzeyde değerlendirmek için kullanılan kısa bir özbildirim ölçeğidir (2). KYASÖ, Hamilton Anksiyete Derecelendirme Ölçeği (3) ve Amerikan Psikiyatri Birliği'nin Ruhsal Bozuklukların Tanısal ve Sayımsal Elkitabı (DSM)'nda yer alan panik bozukluğu ve yaygın anksiyete bozukluğu tanı ölçütlerine dayanılarak geliştirilmiştir ve DSM 5'teki ölçütlerle de uyumludur (4,5). KYASÖ, anksiyete bozukluklarına özgül bir ölçek olmaktan ziyade genel ruhsal ve bedensel anksiyetenin ölçülmesine odaklanmıştır ve böylelikle anksiyete bozukluklarında olduğu kadar majör depresif bozukluk, obsesif kompülsif bozukluk, travma sonrası stres bozukluğu, bedensel belirti bozukluğu, bipolar bozukluklar, yeme bozuklukları gibi diğer bozukluklarda da görülebilen kaygının değerlendirilmesinde yararlıdır $(2,6)$. Çoğu anksiyete ölçeği, tek bir anksiyete bozukluğunun belirtilerinin şiddetini ölçer veya yalnızca belirli anksiyete bozukluklarını değerlendirebilir $(7,8,9)$. Buna karş1lı, KYASÖ hem ruhsal, hem bedensel anksiyete şiddetini tanıdan bağımsız olarak ölçmek amacıyla tasarlanmıştır. Hastalığa özgü ölçekler sadece tanı alan hastalarda kullanılabilirken, genel anksiyete ölçümü anksiyete belirtileri olan herhangi bir hasta için yararlı olabilir (6). KYASÖ kontrol görüşmeleri sırasında süregelen anksiyete belirtilerini sistematik olarak değerlendirmek için de kullanılabilir (2).
Bu çalışmada Türk toplumunda KYASÖ'nün geçerlilik ve güvenilirliğinin tespiti amaçlanmıştır. Varsayımlarımız KYASÖ ve alt ölçek puanlarının hem klinisyen hem özbildirime dayalı ölçek puanları ile pozitif korelasyon göstereceği, KYASÖ'nün anksiyete bozukluğu tanısı alan grubu sağliklı popülasyondan ayırt edebileceği ve Türk toplumunda geçerli ve güvenilir bulunacağ 1 şeklindedir.

\section{Gereç ve Yöntemler}

\section{Katılimcılar}

Araştırmaya Tokat Gaziosmanpaşa Üniversitesi Araştırma ve Uygulama Hastanesi Ruh Sağlı̆̆ ve Hastalıkları Polikliniği'ne Aralık 2018 - Mart 2019 tarihleri arasında ayaktan başvuran, 18 yaş üstü (35.68 $\pm 13.50 \quad$ yıl), \%68.6's1 kadın, $\% 36.9$ 'u evli, \%24'ü 12 yıl veya daha üstü eğitim düzeyine sahip), DSM 5'e göre birincil tanısı anksiyete bozukluğu veya anksiyeteyle yakından ilişkili bir bozukluk (obsesif kompülsif bozukluk veya travma sonras1 stres bozukluğu) olan ( $\mathrm{n}=155, \% 54)$ ve halen veya geçmişte herhangi bir psikiyatrik bozukluk tanısı olmayan $(n=132, \% 46)$ toplam 287 kişi alınd. Katılımcilar arasinda yaygin anksiyete bozukluğu 63 (\%40.6), panik bozukluk 37 (\%23.9), obsesif kompülsif bozukluk 20 $(\% 12.9)$, sosyal anksiyete bozukluğu 18 (\%11.6) ve travma sonrası stres bozukluğu 17 (\%11) kişide mevcuttu. Birincil tanıs1 nörogelişimsel bozukluklar, şizofreni spektrumu ve psikozla giden diğer bozukluklar, bipolar ve ilişkili bozukluklar, depresif bozukluklar ve nörobilişsel bozukluklar, psikotik veya katatonik özellik gösteren bir ruhsal bozukluk veya aktif özkıyım düşüncesi, planı, niyeti olduğunu beyan eden katılımcılar çalışmadan dışlandı. Kontrol grubundaki katılımcılar polikliniğe ayaktan başvuran hastaların yakınlarından oluşturuldu.

\section{İşlem}

Çalışmaya katılmayı kabul eden katılımcılarla poliklinik odasında DSM 5 tanı ölçütlerini esas alan klinik görüşmeye dayalı tanısal 
değerlendirme yapıldı (5). $\quad \mathrm{Bu}$ değerlendirmeye göre katılımcılar Anksiyete Bozukluğu Grubu (AG) ve Sağliklı Kontrol Grubu (KG) olarak iki gruba ayrıldı. Katılımcıların demografik verileri hazırlanmış olan bir forma görüşmeci tarafindan kaydedildi. Daha sonra tüm katılımcılara değerlendirme araçları rastgele bir sıra içerisinde verilerek kendi başlarına doldurabilecekleri sessiz bir odaya alındı. İhtiyaç duyan katılımcılara bu araçların doldurulmasında yardımcı olundu. Tüm görüşmeler ortalama 25-40 dakika sürdü. Ölçüm araçları tamamlandıktan sonra klinisyen tarafindan eksik veya hatalı doldurulan verilerin olup olmadığı kontrol edildi; varsa katılımeı ile birlikte eksiksiz olarak tekrar dolduruldu. Çalışma öncesinde tüm katılımcılardan yazılı bilgilendirilmiş onam formu alındı. Çalışma, Tokat Gaziosmanpaşa Üniversitesi Klinik Araştırmalar Etik Kurulu tarafindan onaylandi.

\section{Çeviri Süreci}

Çalışmada geçerlilik ve güvenilirliği araştırılan ölçekler için öncelikle bu ölçeklerin geliştiricisi ile e-posta ile temasa geçilerek çeviri izni alındı. Daha sonra iki araştırmacı tarafından ölçekler İngilizce'den Türkçe'ye çevrildi. Ölçeklerin özgün halinden habersiz olan bir diğer araştırmacı ve İngilizce dil eğitimi veren bir uzman tarafından ölçek maddeleri Türkçe'den İngilizce'ye geri çevrildi. $\mathrm{Bu}$ dört metin ile özgün ölçekler birbirleriyle karşılaştırılarak üzerinde uzlaşılan ölçek çevirileri elde edildi. Çeviriler, çalışmada kullanılmadan önce polikliniğe başvuran 20 hastaya verilerek doldurulmaları istendi ve anlaşılmakta zorlanılan maddelerin varlı̆̆ 1 açısından değerlendirildi. Bu aşamada ölçek maddelerinde bir değişiklik yapılma ihtiyacı duyulmad.

\section{Değerlendirme Araçları}

Klinikte Yararlı Anksiyete Sonlanım Ölçeği (KYASÖ): Ölçeğin özgün formu (Clinically Useful Anxiety Outcome Scale, CUXOS) kişinin kendisinin doldurduğu 20 sorudan oluşmaktadır. Altı maddelik ruhsal anksiyete ve 14 maddelik bedensel anksiyete alt ölçeği vardır. Ölçekte beşli Likert tipi puanlama kullanılmaktadır ve katılımcinın son bir haftasını değerlendirilmektedir. Ölçeğin iç tutarlılı̆g 1 için Cronbach $\alpha$ değeri 0.95 bulunmuştur. Ayrıca ölçeğin test-tekrar test korelasyonu 0.90 olarak hesaplanmıştır (2).

Durumluk - Sürekli Kayg1 Ölçeği: Bu ölçek her biri 20 maddeden oluşan Durumluk Kayg1 Ölçeği (DKÖ) ve Sürekli Kaygi Ölçeği (SKÖ) isimli iki ölçekten oluşur (10). Ölçeklerden alınan yüksek puanlar, anksiyete düzeylerinin yüksek olduğunu gösterir. DKÖ için 41, SKÖ için 44 puanın klinik düzeyde önemli anksiyeteye işaret ettiği gösterilmiştir (11). Bu çalışmada ölçeklerin Türkçe versiyonları kullanılmıştır (12).

Klinikte Yararlı Depresyon Sonlanım Ölçeği (KYDSÖ): Toplam 18 maddeden oluşan, ilk 16 maddesi depresyonun farkl belirtilerinin şiddetini, son iki maddesi ise depresyon nedeniyle yaşam kalitesi ve işlevselliğin ne düzeyde etkilendiğini sorgulayan bir özbildirim ölçeğidir (13). KYDSÖ'nün Türkçe versiyonunun geçerli ve güvenilir olduğu gösterilmiştir (14).

Klinik Global İzlenim Ölçeği - Şiddet Alt Ölçeği (KGI-Ş): Klinisyenin kendi deneyimlerinden yola çıkarak karşısındaki kişide psikopatolojik bir durum saptamışsa onun şiddetini 1-7 arasındaki bir ölçekte puanladığı değerlendirme aracıdır (15). Bu çalışmada şiddet gruplandırmaları sırasında 13 arasindaki puanlar hafif, 4 puan orta, 5-7 arasındaki puanlar ise şiddetli düzeyde anksiyete olarak ele alınmıştır. KGİ-Ş’nin Türkçe versiyonu kullanılmıştır (16).

\section{İstatistiksel Analiz}

FACTOR 10.8.04 yazılımı ile açıklayıcı faktör analizi için ölçekteki madde sayısı başına en az 5-10 katılımeı gerektiği ve en az 100-200 katılımcıya ihtiyaç olduğu hesaplandı (17). Faktör analizi sirasında, ordinal maddelerin tek değişkenli dağılımları asimetrik olduğundan polikorik korelasyon tercih edildi (18). Çıkarılacak faktör sayısını belirlemede paralel analizden faydalanıldı (19). Faktörlerin çıkarılmasında ağırlıklandırılmamış en küçük kareler yöntemi, döndürme yöntemi olarak oblik 
döndürme kullanıldı. Bütün hesaplamalar için yeniden örnekleme yöntemi ile \%95 güvenilirlik aralığında yanlılığ düzeltilmiş güçlü analizler tercih edildi (20). Çıkarılan faktörlerin ve ölçeğin tamamının iç tutarlılı̆ 1 için Cronbach $\alpha$ değerleri, düzeltilmiş madde - toplam korelasyonları (DMTK) ve madde silinirse Cronbach $\alpha$ değerleri (MSCA), açıklanan varyans, özdeğerler, maddelerin faktörlere yüklenme katsayıları ve ortak etken varyansları hesaplandı. Diğer analizler için MedCalc 17.2 yazılımı kullanıldı (MedCalc Software, Ostend, Belgium). Ölçeklerin birlikte geçerliliği için Pearson korelasyon analizleri, korelasyon katsayıları arasında fark olup olmadığını tespit etmek için Steiger'in Z testi kullanıldı (21). Demografik verilerin dağılımı ve ölçek puanlarına göre grup karşılaştırmalarında verinin türüne göre tek yönlü varyans analizi, bağımsız gruplarda ttesti veya ki-kare testlerinden faydalanıldı. Çoklu grup karşılaştırmaları için Bonferonni düzeltmesi yapıldı.

\section{Bulgular}

\section{Anksiyete Bozukluğu Tanısı Varlı̆̆ına Göre Grup Karşılaştırmaları}

Sosyodemografik özellikler açısından KG'deki katılımcılar daha gençti, daha fazla sayida erkekten oluşuyordu, daha az evlenmişti ve eğitim düzeyleri görece daha düşüktü. Çalışmada kullanılan tüm ölçeklerde $\mathrm{KG}$, AG’ye göre daha düşük puan almıştı (Tablo 1).

Tablo 1. Anksiyete bozukluğu tanısının varlığına göre demografik özellikler ve değerlendirme araçları açısından grup karşılaştırmaları

\begin{tabular}{|c|c|c|c|c|c|}
\hline & $\begin{array}{l}\text { Tüm Grup } \\
(N=287)\end{array}$ & $\begin{array}{c}\mathrm{KG} \\
(n=132)\end{array}$ & $\begin{array}{c}\mathrm{AG} \\
(n=155)\end{array}$ & $t / \chi^{2}$ & $P$ \\
\hline Yaş (yıl) & $35.68(13.50)$ & $27.20(11.05)$ & $42.02(11.57)$ & -10.64 & $<0.001$ \\
\hline Cinsiyet, kadın & $197(68.6)$ & $81(61.4)$ & $116(74.8)$ & 6.01 & 0.014 \\
\hline Eğitim düzeyi, 12 yıl ve üstü & $69(24)$ & $24(18.2)$ & $45(29)$ & 4.60 & 0.032 \\
\hline KYDSÖ puanı & $33.61(14.68)$ & $15.85(7.89)$ & $38.88(11.81)$ & -12.42 & $<0.001$ \\
\hline DKÖ puanı & $40.88(9.41)$ & $36.35(5.06)$ & $44.74(10.50)$ & -8.38 & $<0.001$ \\
\hline KYASÖ puanı & $24.75(20.99)$ & $7.66(5.62)$ & $39.31(18.11)$ & -19.30 & $<0.001$ \\
\hline KYASÖ-R puanı & $12.70(9.53)$ & $4.70(3.60)$ & $19.52(7.49)$ & -20.77 & $<0.001$ \\
\hline KYASÖ-B puanı & $12.05(12.42)$ & $2.95(2.92)$ & $19.79(12.17)$ & -15.52 & $<0.001$ \\
\hline
\end{tabular}

Sonuçlar ortalama (stardart sapma) veya sıklık (yüzde) olarak verilmiştir. Bonferonni düzeltmesi sonrası ölçekler açısından grup karşılaștırmalarında istatistiksel anlamlılı için $p<0.006$ değeri kabul edilmiștir. KG, sağllklı kontrol grubu; AG, anksiyete bozukluğu grubu; DKÖ, Durumluk Kaygl Ölçeği; SKÖ, Sürekli Kaygl Ölçeği; KGİ-Ş, Klinik Global İzlenim Ölçeği - Şiddet Alt Ölçeği; KYDSÖ, Klinikte Yararlı Depresyon Sonlanım Ölçeği; KYASÖ, Klinikte Yararlı Anksiyete Sonlanım Ölçeği; KYASÖ-R, Klinikte Yararlı Anksiyete Sonlanım Ölçeği - Ruhsal Anksiyete Alt Ölçeği; KYASÖ-B, Klinikte Yararlı Anksiyete Sonlanım Ölçeği Bedensel Anksiyete Alt Ölçeği

\section{Yapı Geçerliliği İncelemesi}

Verilerin faktör analizi için uygunluğuna bakılan Kaiser-Meyer-Olkin testinin sonucu 0.96 saptand1. Bartlett küresellik istatistiği anlamliyd $1(\chi 2=5983.4, \mathrm{p}=0.0001)$. Paralel analiz sonuçları iki faktör çıkarılmasının uygun olacağını gösterdi. Yapılan açıklayıcı faktör analizi sonucunda madde 9-14 birinci faktörü, madde 1-6 ikinci faktörü oluşturdu. Yedinci ve sekizinci maddelerin her iki faktöre de yüklendiği görüldü. Bu maddelerin içerik açısından gerginlik ve sinirlilik ile ilgili olduğu görüldüğünden Türkçe versiyonda bu iki maddenin ikinci faktörde bırakılmasının daha uygun olacağı düşünüldü. Buna göre birinci faktör "Bedensel (Somatik) Anksiyete (KYASÖ-B)", ikinci faktör "Ruhsal (Psişik) Anksiyete (KYASÖ-R)" olarak isimlendirildi. Maddelerin ilgili faktörlerine yüklenmeleri birinci faktörde 0.503-0.848, ikinci faktörde ise 0.386-0.989 aralığında değişti. Böylelikle hiçbir maddenin 0.300 yüklenme değerinin altında olmadığı görüldü. Birinci faktörün özdeğeri 11.05, ikinci faktörün 1.34 idi. Faktör analizi sonrasında kümülatif olarak 
açıklanan varyans \%61.96 (birinci faktör için değer \%50'nin üzerinde olması nedeniyle $\% 55.25$, ikinci faktör için \%6.71) idi. $\mathrm{Bu}$ yeterli bulundu (Tablo 2).

Tablo 2. Ölçek maddelerinin faktörlere yüklenmeleri, özdeğerler, ortak etken varyansları, açıklanan varyansların dağılımı, iç tutarlılıkları, düzeltilmiş madde-toplam korelasyonları ve madde silinirse Cronbach $\alpha$ değerleri

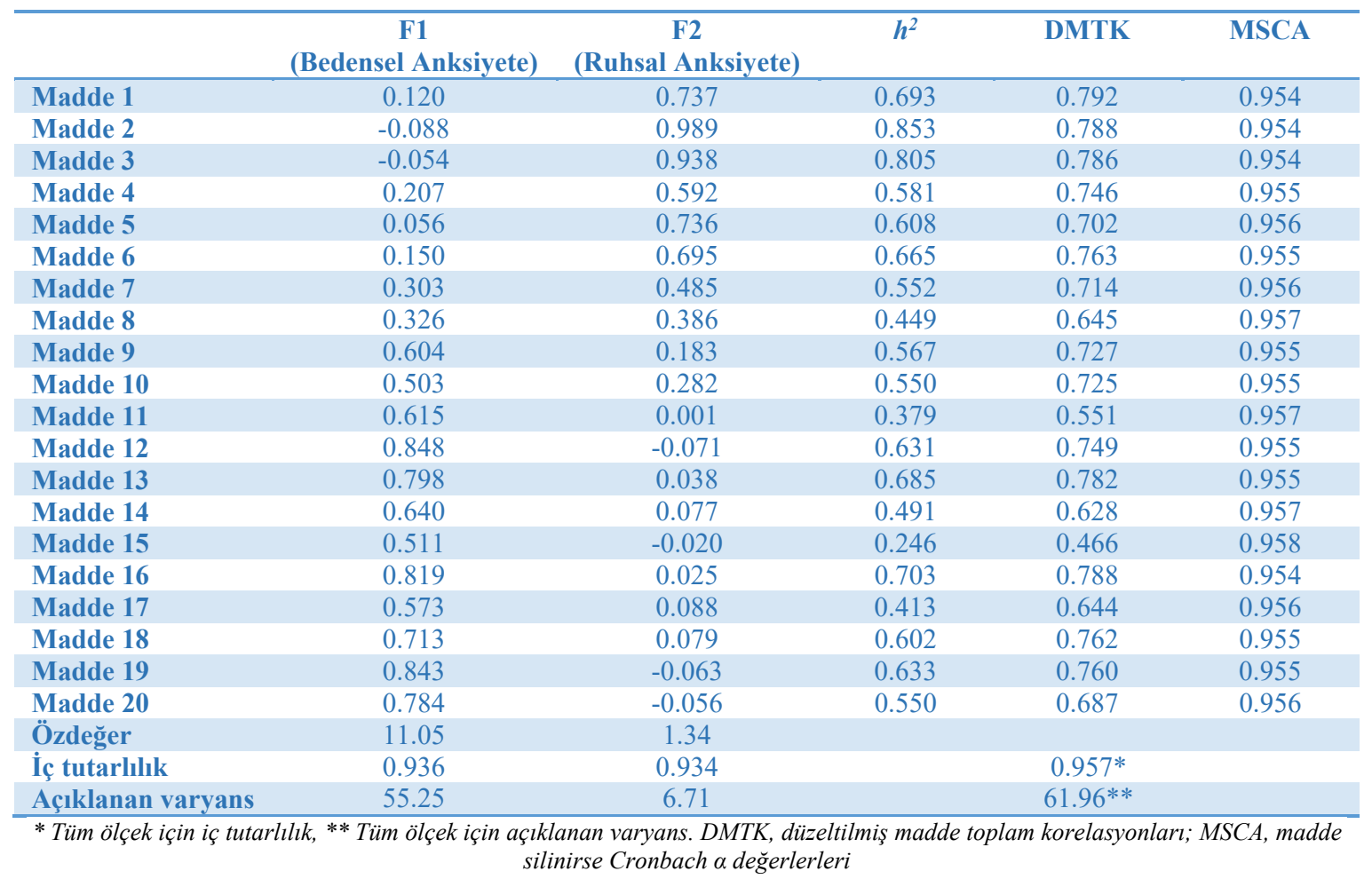

\section{Birlikte Geçerlilik İncelemeleri}

KYASÖ, KYASÖ-R ve KYASÖ-B'nin demografik değişkenler, KGİ-Ş, DKÖ, SKÖ ve KYDSÖ ile korelasyon analizleri yapıldı. Klinisyen değerlendirmeleri (KGİ-Ş puanı) ve özbildirimlerle (DKÖ ve SKÖ puanları) ölçek puanları arasında pozitif yönlü korelasyon saptand. $\mathrm{Bu}$ sonuçlar KYASÖ ve alt ölçeklerinin birlikte geçerliliğini desteklemektedir. Ayrıca ölçeklerin depresyon puanları ile orta büyüklükte ve pozitif yönlü korele olduğu görüldü. $\mathrm{Bu}$ sonuç depresyon ve anksiyete belirtileri arasındaki örtüşmeyi ve farklı kategorik tanı grupları arasında dahi benzer semptomatolojinin mevut olabileceğini hatırlatmaktadır (Tablo 3).

Tablo 3. Ölçekler arasındaki korelasyon ilişkisinin sonuçları

\begin{tabular}{llll}
\hline & \multicolumn{1}{c}{ KYASÖ } & \multicolumn{1}{c}{ KYASÖ-R } & \multicolumn{1}{c}{ KYASÖ-B } \\
\hline Yaş & $0.383^{*} *$ & $0.383 * *$ & $0.357 *$ \\
\hline Cinsiyet & $-0.185 * *$ & $-0.140 *$ & $-0.196 * *$ \\
\hline Medeni durum & $0.179 * *$ & $0.171 * *$ & $0.171 * *$ \\
\hline Eğitim düzeyi & $0.175 * *$ & $0.139 *$ & $0.182 * *$ \\
\hline DKÖ & $0.723 * *$ & $0.664 * *$ & $0.713 * *$ \\
\hline SKÖ & $0.709 * *$ & $0.658 * *$ & $0.694 *$ \\
\hline KYDSÖ & $0.498 * *$ & $0.508 * *$ & $0.418 * *$ \\
\hline KGİ-Ş & $0.436 * *$ & $0.491 * *$ & $0.399 *$ \\
\hline KYASÖ & 1 & $0.943 * *$ & $0.967 * *$ \\
\hline KYASÖ-R & $0.943 * *$ & 1 & $0.826 * *$ \\
\hline KYASÖ-B & $0.967 * *$ & $0.826 * *$ & 1 \\
\hline
\end{tabular}


Cinsiyet, Kadın = 0, Erkek=1; medeni durum, Bekar, Boşanmış, Dul, Ayrı Yaşıyor = 0, Evli = 1; eğitim düzeyi, 12 yıldan az =0, 12 yl veya daha fazla $=1$ olarak kodlanmıștır. ${ }^{*} p<0.05, * * p<0.01$. DKÖ, Durumluk Kaygl Ölçeği; SKÖ, Sürekli Kaygl Ölçeği; KYDSÖ, Klinikte Yararl Depresyon Sonlanım Ölçeği; KGI-Ş, Klinik Global İzlenim Ölçeği - Şiddet Alt Ölçeği; KYASÖ, Klinikte Yararlı Anksiyete Sonlanım Ölçeği; KYASÖ-R, Klinikte Yararlı Anksiyete Sonlanım Ölçeği - Ruhsal Anksiyete Alt Ölçeği; KYASÖB, Klinikte Yararlı Anksiyete Sonlanım Ölçeği - Bedensel Anksiyete Alt Ölçeği

\section{Ayırt Edici Geçerlilik İncelemeleri}

KYASÖ, KYASÖ-R ve KYASÖ-B'nin anksiyete bozukluğu tanısı alan ve almayan grupları ayırt edebildiğine dair sonuçlar Tablo 1 'de verilmiştir $(\mathrm{p}<0.001)$. Klinisyenlerin yaptı̆̆ değerlendirmeye ve özbildirime dayalı olarak saptanan anksiyete şiddetlerine göre gruplandırma yapıldığında KYASÖ ve alt ölçeklerinin başarılı şekilde ayırt edicilik yaptığ 1 ( $<0.001)$ saptanmıştır (Tablo 4).

Ayrıca KYASÖ ve alt ölçeklerinin DKÖ, SKÖ'de daha büyük olmak üzere, KYDSÖ ile olan korelasyonları arasında istatistiksel olarak anlamlı fark olduğu tespit edilmiştir (Tablo5)

Tablo 4. Klinisyen değerlendirmesi ve özbildirime göre şiddet gruplandırmalarının KYASÖ ve alt ölçekleri tarafından ayırt ediciliği

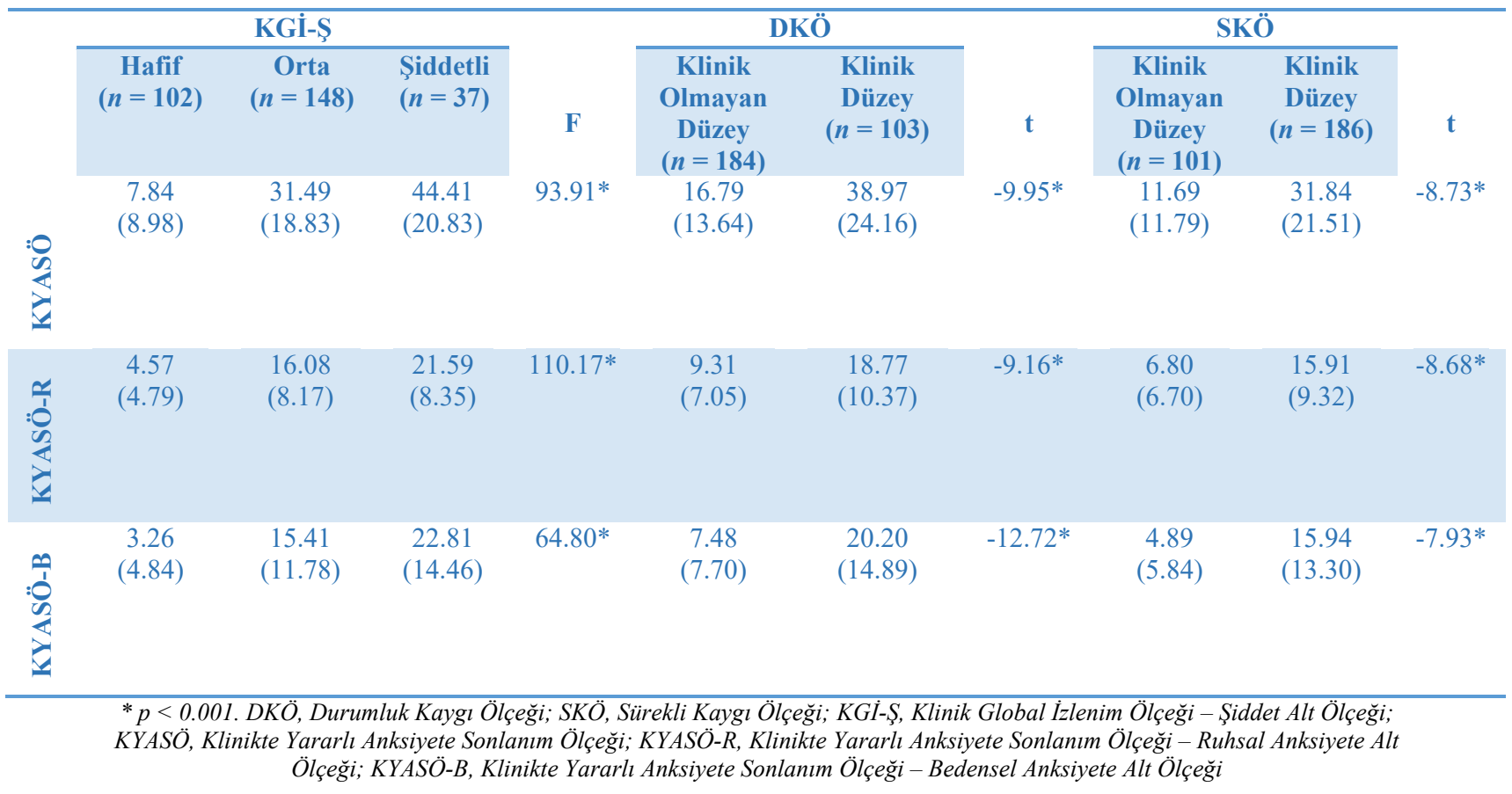

Tablo 5. Depresyon ve anksiyete değerlendirme ölçekleri ile KYASÖ ve alt ölçekleri arasındaki korelasyonların farklılıklarının karşılaştırılması

\begin{tabular}{|c|c|c|c|c|c|c|}
\hline & \multicolumn{2}{|c|}{ KYASÖ } & \multicolumn{2}{|c|}{ KYASÖ-R } & \multicolumn{2}{|c|}{ KYASÖ-B } \\
\hline & $Z$ & $p$ & $Z$ & $p$ & $Z$ & $p$ \\
\hline DKÖ-KYDSÖ & 4.84 & $<0.001$ & 3.19 & 0.001 & 6.01 & $<0.001$ \\
\hline SKÖ-KYDSÖ & 4.48 & $<0.001$ & 3.06 & 0.001 & 5.53 & $<0.001$ \\
\hline
\end{tabular}




\section{Güvenilirlik İncelemeleri}

KYASÖ'nün tamamı ve her iki alt ölçeği için iç tutarlılık yüksek bulunmuştur (Cronbach $\alpha$ değerleri KYASÖ için 0.957, KYASÖ-B için 0.936 ve KYASÖ-R için 0.934). Madde çıkarılması ile ölçeğin tümünde iç tutarlılıkta önemli bir değişiklik gözlenmemiştir. DMTK değerleri $0.466-0.792$ arasında değişmiştir. $\mathrm{Bu}$ sonuçlar, ölçeğin güvenilir olduğunu göstermektedir (Tablo 2).

\section{Tartışma ve Sonuç}

$\mathrm{Bu}$ çalışmada KYASÖ’nün Türk toplumundaki geçerlilik ve güvenilirliği araştırılmıştır. Yapılan istatistiksel analizlerin sonuçları, çalışmanın başlangıcındaki varsayımlarımızın hepsinin karşılandığını, KYASÖ'nün rutin klinik pratikte kullanılmak üzere önerilebilecek bir anksiyete derecelendirme ölçeği olabileceğini göstermiştir.

KYASÖ kendisini birçok açıdan mevcut ölçeklerden ayırır. Çoğu anksiyete derecelendirme ölçeği, özgül bir anksiyete bozukluğunun belirtilerini değerlendirir. Buna karşıllk, KYASÖ ruhsal ve bedensel anksiyete şiddetini genel olarak ölçmektedir. $\mathrm{Bu}$ yaklaşımın avantaj ve dezavantajları vardır. Bozukluğa özgül ölçekler spesifik tanı alan hastalarda kullanılabilirken, genel anksiyete ölçümü herhangi bir psikiyatrik tanısı olan hastalar için de yararlı olabilir. Aynı şekilde, madde kullanımı, uyum bozukluğu ve bedensel belirti bozukluğu tanıları olan hastaların, teşhis edilebilir bir anksiyete bozukluğunun yokluğunda dahi ruhsal ve bedensel anksiyete derecelendirme ölçek maddelerinde genellikle yüksek puan aldığ bulunmuştur (2). $\mathrm{Bu}$ gibi durumlarda bozukluğa özgül ölçeklerin klinik uygulamada kullanılması zor olabilir. Çünkü birden fazla tanısı olan hastaların her bir tanıya özgül ölçekleri tamamlamaları gerekecektir. Anksiyete şiddetini ölçen başka ölçekler olsa $\mathrm{da}$, uygulanmalarındaki zorluk veya telif hakk1 sebebiyle rutin klinik uygulamada kullanılmaları daha az tercih sebebi olabilir $(22,23)$. KYASÖ, KYDSÖ gibi kısa, kolay puanlanan ve klinisyenler tarafindan ücretsiz olarak kullanılabilen bir ölçektir $(2,24)$.

Yap1 geçerliliğini incelemek için yapılan açıklayıcı faktör analizlerinde tüm sonuçlar KYASÖ'nün geçerliliğini doğrulamıştır. Ancak özgün ölçekten farklı olarak KYASÖ’nün Türkçe versiyonun da gerginlik ve sinirlilikle ilgili maddelerin ruhsal anksiyete alt ölçeğinde daha kuvvetli bir yüklenme göstermiştir. Bunda gerginlik ve sinirliliğin ruhsal belirti olarak yorumlanması, ayrica toplumlar arasındaki kültürel farkl111kların rolü olabilir. Madde içeriklerinden ve istatistiksel sonuçlardan yola çıkarak bu maddelerin özgün ölçekte olduğundan farklı olarak ruhsal anksiyete alt ölçeğinde bırakılmasına karar verilmiştir. Diğer ölçek maddelerinin özgün ölçekteki faktör yüklenmeleri aynen korunmuştur (2). Öte yandan ölçeğin iki faktörlü yapısı doğrulanmış olmakla birlikte faktörlerin özdeğerleri arasındaki yaklaşı on katlık fark tek faktörlü bir yapının da düşünülmesi gerekebileceğini akla getirmektedir. Aslında bu tek faktörlü yapı önermesinin özgül bir anksiyete bozukluğunun şiddetini derecelendirmek için geliştirilmekten ziyade genel bir anksiyete durumunu tespit etmeye dönük olan KYASÖ için daha kabul edilebilir bir sonuç olabileceği düşünülmektedir. Ruhsal ya da bedensel anksiyetenin şiddetini tanıdan bağımsız olarak değerlendirdiğimizde tek bir anksiyete şiddeti derecelendirmesi daha anlamlı sonuçlar verecektir.

Ölçeklerin birlikte geçerlilik analizi sonuçlarına bakıldığında, anksiyetenin şiddetinin hem klinisyen değerlendirmesi, hem de özbildirime dayalı değerlendirmelerin orta büyüklükte korele olduğu görülmüştür. $\mathrm{Bu}$ sonuçlar ölçeğin birlikte geçerliliğini desteklemektedir ve özgün çalışmada benzer sonuçlar bildirilmiştir (2). Öte yandan depresyonun şiddeti ile olan orta büyüklükteki korelasyon ve kimi demografik etmenlerle gözlenen korelasyonlar KYASÖ'nün geçerliliği ile ilgili ek bilgiler vermektedir. Depresyon ve anksiyete belirtileri arasında sık 
gözlenen örtüşme ve her iki durumun sıklıkla birbirlerine eşlik ediyor olmaları orta büyüklükteki korelasyonu açıklayabilir. Depresyon ölçekleriyle olan benzer bir korelasyon düzeyi özgün geçerlilik ve güvenilirlik çalıșmasında da bildirilmiștir (2). Alanyazındaki verilerden yola çıkılarak anksiyete ile yaş $(25,26)$, cinsiyet $(27,28)$ medeni durum $(29,30)$ ve eğitim düzeyi $(31,32)$ arasındaki ilişkiye odaklanan çalışmalar ile mevcut sonuçların kısmen örtüştüğü görülmüştür. Örtüşmeyen sonuçlar özellikle kültürel farklılıklar, örneklemin yaş aralığı ve geriyatrik popülasyona özgül bir değerlendirmenin yapılmamış olması ile açiklanabilir.

KYASÖ'nün özgün çalışmasında iç tutarlılık güvenirlik katsayısı ölçeğin bütününde ve alt ölçeklerde yüksek (sırasıly KYASÖ, KYASÖ-B ve KYASÖ-R için Cronbach $\alpha=$ $0.95,0.93$ ve 0.90 ) bulunmuștur (2). KYASÖ'nün Türkçe formunda ise iç tutarll1lk güvenilirlik katsayısı Cronbach $\alpha=0.957$ bulundu. KYASÖ-B ve KYDSÖ-R için hesaplanan ic tutarlılık katsayıları da beklendiği şekilde yüksek ve özgün ölçek için hesaplanan değerlere yakındı (sırasıyla 0.936

\section{KAYNAKLAR}

1. Bandelow B, Michaelis S. Epidemiology of anxiety disorders in the 21 st century. Dialogues Clin Neurosci. 2015;17:327-35.

2. Zimmerman M, Chelminski I, Young D, et al. A clinically useful anxiety outcome scale. $J$ Clin Psychiatry. 2010;71:534-42.

3. Hamilton M. The assessment of anxiety states by rating. Br J Med Psychol. 1959;32:50-5.

4. Zimmerman M, Chelminski I, Young D, et al. A clinically useful self-report measure of the DSM-5 mixed features specifier of major depressive disorder. $J$ Affect Disord. 2014;168:357-62.

5. American Psychiatric Association: Diagnostic and Statistical Manual of Mental Disorders. (2013), 5th ed. Arlington, VA: American Psychiatric Association.

6. Jeon SW, Han C, Ko $\mathrm{YH}$ et al. A Korean validation study of the Clinically Useful Anxiety Outcome Scale: Comorbidity and ve 0.934). Böylelikle ölçeklerin güvenilirliği doğrulanmış oldu.

Klinik uygulamada spesifik tanı grupları dışında anksiyete semptom şiddetini ölçen, kısa sürede uygulanabilen bir ölçeğin geçerli ve güvenilir bulunması çalışmanın güçlü yönleri arasındadır. Öte yandan tan1 görüşmelerinin rutin klinik değerlendirmelere dayanması ve yapılandırılmış görüşmeler uygulanmaması, test-tekrar test güvenilirlik analizlerinin yapılmamış olması çalışmanın k1sitlılıklardandır.

\section{Sonuc}

KYASÖ'nün Türk toplumundaki bu geçerlilik ve güvenilirlik çalışması, bazı kısıtlılıklarına rağmen, ölçeğin klinikte kullanım için uygun olduğunu göstermiştir. Gelecekteki çalışmalar, semptom şiddetini gösteren puan aralıklarını tespit etmek ve doğrulamak için KYASÖ'nün klinisyen tarafından değerlendirilen bir ölçüm aracıyla semptom şiddeti ölçümünü karşılaştırmalıdır. Ayrıca farklı demografik ve klinik özellikleri olan hasta gruplarında ölçeğin kullanılabilirliğinin tekrarlanması gereklidir. differentiation of anxiety and depressive disorders. PLoS One. 2017;12:e0179247.

7. Davidson JR, Miner CM, De Veaugh-Geiss J, et al. The Brief Social Phobia Scale: a psychometric evaluation. Psychol Med. 1997;27:161-6.

8. Meyer TJ, Miller ML, Metzger RL, et al. Development and validation of the Penn State Worry Questionnaire. Behav Res Ther. 1990;28:487-95.

9. Shear MK, Brown TA, Barlow DH, et al. Multicenter collaborative panic disorder severity scale. Am $J$ Psychiatry. 1997;154:1571-5.

10. Spielberger CD, Gorsuch RL, Lushene R, et al. (1983), Manual for the State-Trait Anxiety Inventory. Palo Alto, CA: Consulting Psychologists Press.

11. Ercan I, Hafizoglu S, Ozkaya G, et al. Examining cut-off values for the state-trait 
anxiety inventory. Argent Clin Psic. 2015, 20:144-8.

12. Öner N, Le Compte A. (1983). Durumluk Sürekli Kaygı Envanteri El Kitabı. İstanbul: Boğaziçi Üniversitesi Yayınları.

13. Zimmerman M, Posternak MA, Chelminski I. Using a self-report depression scale to identify remission in depressed outpatients. $\mathrm{Am} \mathrm{J}$ Psychiatry. 2004;161:1911-3.

14. Çelikbaş Z, Batmaz S, Yüncü ÖA, et al. Assessing depression with anxious distress and mixed features: The validity and reliability of the Turkish version of the clinically useful depression outcome scale. $J$ Clin Psy. 2020;23: 43-55.

15. Guy W. ECDEU Assessment Manual for Psychopharmacology. Revised US Dept Health, Education and Welfare publication (ADM), Rockville, Md; NIMH, 1976;76-338.

16. Aydemir Ö, Köroğlu E. (2017). Psikiyatride kullanılan klinik ölçekler. Hekimler Yayın Birliği.

17. Lorenzo-Seva U, Ferrando PJ. FACTOR: a computer program to fit the exploratory factor analysis model. Behav Res Methods. 2006; 38:88-91.

18. Muthén B, Kaplan D. A comparison of some methodologies for the factor analysis of nonnormal likert variables. Brit $J$ Math Stat Psy. 1985;38:171-89.

19. Timmerman ME, Lorenzo-Seva U. Dimensionality assessment of ordered polytomous items with parallel analysis. Psychol. Methods. 2011;16:209-20.

20. Lambert ZV, Wildt AR, Durand RM. Approximating confidence intervals for factor loadings. Multivariate Behav Res. 1991;26:421-34

21. Steiger JH. Tests for comparing elements of a correlation matrix. Psychol Bull. 1980;87:24551 .

22. Zung WW. A rating instrument for anxiety disorders. Psychosomatics. 1971;12:371-9.
23. Beck AT, Epstein N, Brown G, et al. An inventory for measuring clinical anxiety: psychometric properties. $J$ Consult Clin Psychol. 1988;56:893-7.

24. Zimmerman M, Chelminski I, McGlinchey JB, et al. A clinically useful depression outcome scale. Compr Psychiatry. 2008;49:131-40.

25. Brenes, GA, Knudson M, McCall WV, et al. Age and racial differences in the presentation and treatment of generalized anxiety disorder in primary care. J. Anxiety Disord. 2008;22:1128-36

26. Brenes GA. Age differences in the presentation of anxiety. Aging Ment Health. 2006;10:298-302.

27. McLean CP, Asnaani A, Litz BT, et al. Gender differences in anxiety disorders: prevalence, course of illness, comorbidity and burden of illness. J Psychiatr Res. 2011;45:1027-35.

28. Christiansen DM. (2015). Examining sex and gender differences in anxiety disorders. A fresh look at anxiety disorders: InTechOpen.

29. Ta VP, Gesselman AN, Perry BL, et al. Stress of singlehood: Marital status, domain-specific stress, and anxiety in a national US sample. $J$ Soc Clin Psychol. 2017;36:461-85.

30. Scott KM, Wells JE, Angermeyer M, et al. Gender and the relationship between marital status and first onset of mood, anxiety and substance use disorders. Psychol. Med. 2010; 40:1495-505.

31. Bjelland I, Krokstad S, Mykletun A, et al. Does a higher educational level protect against anxiety and depression? The HUNT study. Soc. Sci. Med. 2008;66:1334-45.

32. Karg RS, Bose J, Batts KR, et al. Past Year Mental Disorders among Adults in the United States: Results from the 2008-2012 Mental Health Surveillance Study. In: CBHSQ Data Review. Rockville (MD): Substance Abuse and Mental Health Services Administration (US). 2012:1-19. 